\title{
資源変動モデルによる港湾周辺海域のウバガイ稚貝の 分布・成長特性の検討
}

\author{
渥美洋一* • 石 澤 健 志** - 國田 淳**・関口信一郎*** \\ 谷野賢二 ${ }^{* * * *}$. 中村義治 ${ }^{* * * *} \cdot$ 三船修司 ${ }^{* * * * * *} \cdot$ 山下俊彦
}

\section{1.はじめに}

生物の多様性や, 生態系に配慮した沿岸域開発への要 請が高まる中で,「自然調和型漁港づくり推進事業」や, 「エコポートモデル事業」に代表される，自然と共生する 海洋構造物の開発が積極的に取り組まれている.

一方，総和としての環境保全だけでなく，環境創造ま で含む，日本型ミティゲーションのあり方が議論されて いる.このような中で, 自然と共生する海洋構造物の持 つ「水産生物保全・増殖効果」を, 適切なモニタリング により定量化することは勿論重要であるが, それだけで は不十分であり, 防波堤等の外郭施設配置を,「水産生物 保全・増殖効果」の視点加ら見た, 波浪・流況・底質等 の最適制御技術として確立し, 港湾 - 漁港計画等に反映 することを可能にし，その効果を予測評価することが必 要となると考えられる。

ウバガイは, 浅海砂浜海域に生息する大型の潜砂性二 枚貝であり, 建設された構造物周辺域に, 密度の高い分 布域が形成されることから，構造物の影響を見る上で, 指標性が高いことが明田ら（1993）により検討されてい る. 海洋構造物と最も関連が深い波浪と, 二枚貝の関連 については, 山下ら（1995）は, 貝の潜砂速度と地形侵 食速度を比較することで, 貝の露出・移動限界を設定し, 海中に露出した稚貝の形状等による移動特性等を, 振動 流水槽による実験で明らかにしている。 また，中村ら （1995）は, 漂砂モデルを応用し, 閉鎖性水域である浜中 湾における現地調査に基づく, 波浪による岸沖方向の移 動モデルにより, 資源量変動を解析している.

本研究では，二枚貝に関するこれらの既往知見を基礎 とし, 苫小牧海域の代表有用種であるウバガイの稚貝期 を対象として, 平成 7,8 年度の現地調査と室内実験に 基づき, 成長段階別の資源量分布, 餌料環境, 及び水質・ 底質等の生息環境特性等を明らかにした。そして,成長・

\footnotetext{
$*$ 正会員 北海道開発局苫小牧港湾建設事務所第二計画課

${ }^{* *} \quad$ 北海道開発局苫小牧港湾建設事務所第二計画課

*** 工修 北海道開発局苫小牧港湾建設事務所長

**** 正会員 工博 北海道東海大学教授工学部海洋開発工学科

***** 水博 水産庁中央水産研究所

****** 正会員旦本データーサービス株式会社

******* 正会員 工博 北海道大学大学院助教授工学研究科
}

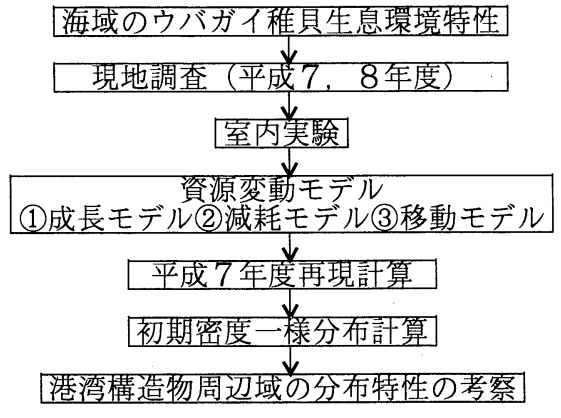

図-1 検討フロー

減耗・移動の 3 つのモデルからなる資源変動モデルを, 平均殼長と資源量分布の 2 点から, 計 13 回の現地調査の 時系列変化を十分現況再現することで構築した.

ここで, 移動モデルは波浪と海浜流を駆動力とし， あ る個体群をラグランジュ的に追跡するものである。また 減耗モデルでは,「シルト含有率」,「波動流速」,「打ち上 げ」の 3 要因を考慮した.

最後に，港湾周辺域におけるウバガイ稚貝の資源分布 特性と, 港湾構造物との関係を資源変動モデルを用い解 析した. 本研究の検討フローを図一1に示す.

\section{2. 現 地 観 測}

本調査では, 現地観測により把握したウバガイ稚貝の 分布・成長状況が, ウバガイ稚貝の資源変動モデルによ り，いかに表現できるかという点が，重要なポイントで ある. 従ってモデルによる再現性を多角的に評価するた めに, (1)測線別, (2)水深別, (3)時系列変化の 3 点から, 稚貝の分布・成長状況を把握することを目的とし, 現地 観測を実施した (図一 2,3$)$. 平成 7 年度には, 構造物近 傍か否かを考慮し, 海域に 3 測線を設け, 7 回の現地調 查を実施した。

\section{3. 資源変動モデルについて}

ウバガイ稚貝の資源変動モデルは, 貝の成長, 減耗, 移動の 3 つのモデルにより構成され,そのフローを図一 に示す. 


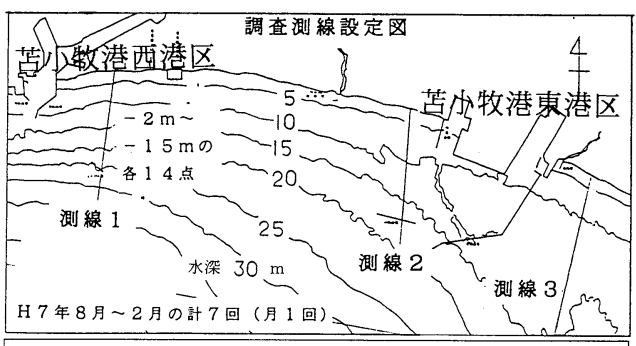

調查項目表

\begin{tabular}{|c|c|c|}
\hline 砂面変動 & 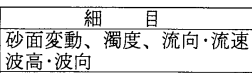 & $\begin{array}{l}\text { 備 } \quad \text { 考 } \\
\text { H7年度测線 } 2(-4,-6,-12) \\
\text { H8年度 测線1 } 1(-4,-6,-12)\end{array}$ \\
\hline $\begin{array}{l}\text { 個体数分布. } \\
\text { 成長状況 }\end{array}$ & 個体数、重量、款長 & 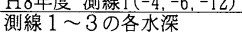 \\
\hline 場の生息環境 & 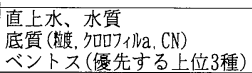 & 測線 1～3の各水深 \\
\hline
\end{tabular}

図-2 平式 7 年度調査位置図

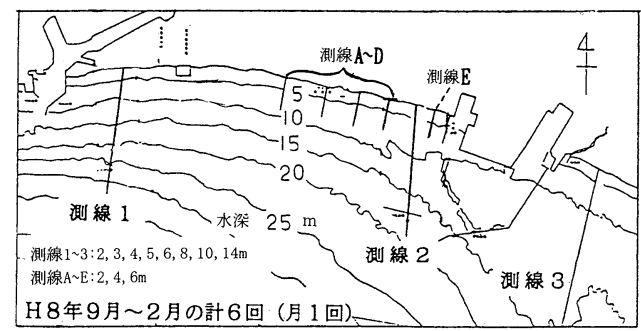

図一 3 平成 8 年度調査位置図

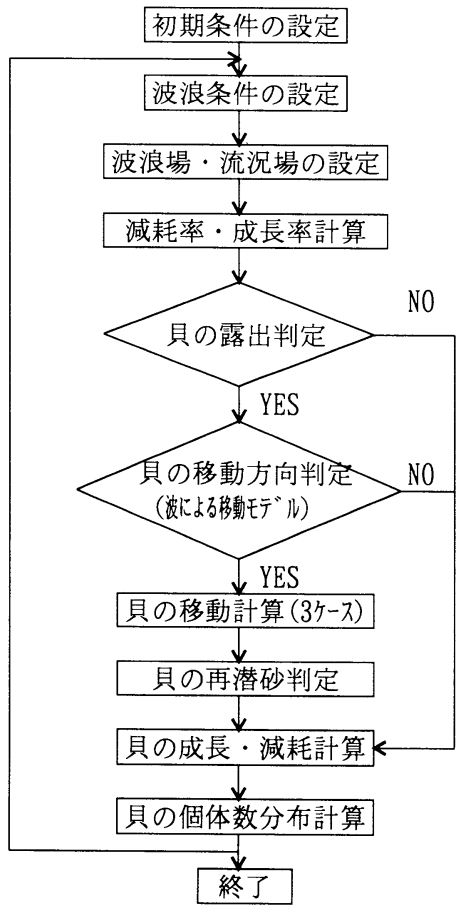

図-4 資源変動モデルフロー

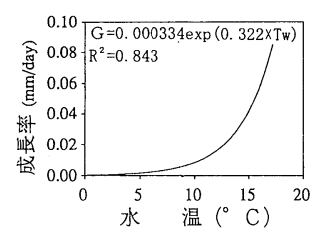

図一5 水温一成長率 相関図

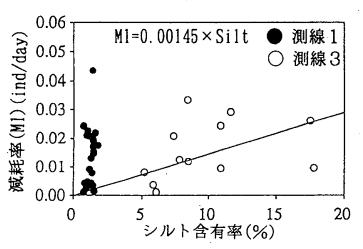

図一6 シルト含有率一減耗率 相関図（測点別）

\section{1 貝の成長モデル}

稚貝の成長 (平均殼長) は, 平成 7,8 年度のクロロ フィル $\mathrm{a}$ 等の現地調査により, この海域には 1 年を通し て, 貝の成長に十分な慨料があることが分かったので, 貝の成長率 $G$ は, 水温 $T w$ のみの関数として次式で与え た（図一5).

$$
G=0.000334 \exp \left(0.322 \times T_{w}\right)
$$

\section{2 貝の減耗モデル}

稚貝の減耗要因としては, シルト含有率 $S_{i}$, 波動流速 $U_{m}(\mathrm{~cm} / \mathrm{s})$, 打ち上げの 3 要因の和とした.

シルトによる減耗率 $M_{1}$ (ind/day) は, 平成 7 年度調査 結果より, 波 (流速) による減耗効果を考慮し, 水深 $5 \mathrm{~m}$ 以深の調査点毎の個体数の減耗率と, シルト含有率の分 布図より（2）式の様に求めた.

$$
M_{1}=0.00145 \times S_{i}
$$

測線 1 のシルト含有率は $2 \%$ 末満で相関式からはずれ ている。これは，波高 2 乗平均の累積と，減耗率が概ね 対応していることから，波による流速の減耗効果の影響 と考えられる。

波（流速）による減耗率 $M_{w}$ (ind/day) は, 山下・松岡 (1994), 平野 (1996) の研究を参考に式（3）で与えた.

$$
M_{w}=0.020 \times\left(U_{m} / 60\right)^{2}
$$

ここで $U_{m}$ は，波動流速（cm/s）である.

打ち上げについては，波浪等の外力により，水深 $1 \mathrm{~m}$ 以浅に移動させられた貝は，陸上に打ち上げられる可能 性が強いので，全て死亡するとした。

\section{3 貝の移動モデル}

貝の露出判定は, 山下ら（1995）の研究成果を基に, 波動流速により, 貝の潜砂速度よりも大きい地形侵食速 度が発生した場合とした。移動外力については, (1)海浜 流のみ, (2)波浪のみ, (3)波浪と海浜流の 3 条件について 計算し，再現性を検証することとした。波による貝の移 動方向は, アーセル数 $U_{r}$ とハーレマイヤーの $\phi$ を用い て, 中村ら（1995）が整理したダイヤグラムにより判定 するものとした. 貝の正味の移動距離は, 現在のところ 見積もる方法が確立していないので, 本論文では, 水粒 子移動距離の $1.5 \%$ とした.また, 貝の再潜砂判定は, 山 下ら（1997）の結果を用いた。 
表一1 資源変動モデルの計算条件及び手法の比較

\begin{tabular}{|c|c|c|c|c|}
\hline \multicolumn{2}{|c|}{ 計算条件 } & \multicolumn{3}{|c|}{ 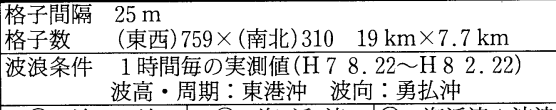 } \\
\hline \multirow{5}{*}{ 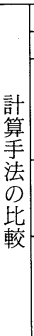 } & & (1) 波 浪 & (2) 海 浜 流 & (3) 海浜流+波浪 \\
\hline & 露出条件 & （波による地形侵食 & 速度)/(貝の潜砂速 & 度) $\geqq 1.0$ \\
\hline & 移動方向 & $\begin{array}{l}\text { アーセル数とハー } \\
\text { レマイヤーの } \\
\text { を用いたダイヤグ } \\
\text { ラムによる }\end{array}$ & $\begin{array}{l}\text { 海浜流ベクトル方 } \\
\text { 向 }\end{array}$ & \multirow{2}{*}{$\begin{array}{l}\text { 海浜流及び波浪に } \\
\text { よるる個別の移動ベ } \\
\text { クトルの合成ベク } \\
\text { トル }\end{array}$} \\
\hline & 動 量 & $\begin{array}{l}\text { 底層流速による最 } \\
\text { 大 移 動 距 離 の } \\
1.5 \%\end{array}$ & $\begin{array}{l}\text { 海浜流速と貝の移 } \\
\text { 動式より計算 }\end{array}$ & \\
\hline & 移動特性 & $\begin{array}{l}\text { 対象領域全体での } \\
\text { 岸沖方向移動 }\end{array}$ & $\begin{array}{l}\text { 海浜流卓越領域 } \\
\text { ・水深約 } 5 \mathrm{~m} \text { 以浅 } \\
\text { ・中央水路西側及 } \\
\text { び東港東側領域 }\end{array}$ & $\begin{array}{l}\text { 両移動モデルの特 } \\
\text { 性を反映し, 全領 } \\
\text { 域に適合 }\end{array}$ \\
\hline
\end{tabular}

表-2 平成 7 年度調查期間の時化のプロフィール

上段 回

下段 出現率 $(\%)$

\begin{tabular}{|c|c|c|c|c|c|}
\hline \multirow{2}{*}{$\begin{array}{l}\text { 期 間 } \\
\text { (経過時間) }\end{array}$} & \multicolumn{3}{|c|}{ 波 高 } & \multicolumn{2}{|l|}{ (m) } \\
\hline & $\sim 0.5$ & $0.5 \sim 1.0$ & $1.0 \sim 2.0$ & $2.0 \sim$ & 計 \\
\hline $\begin{array}{c}\mathrm{H} 78.22 \sim 9.20 \\
\text { (721 時間) }\end{array}$ & $\begin{array}{r}357 \\
(49.5) \\
\end{array}$ & $\begin{array}{c}261 \\
(36.2) \\
\end{array}$ & $\begin{array}{c}103 \\
(14.3) \\
\end{array}$ & $\begin{array}{c}0 \\
(0.0) \\
\end{array}$ & $\begin{array}{r}721 \\
(100) \\
\end{array}$ \\
\hline $\begin{array}{c}\text { H 7 8.22 10. } 20 \\
(1441 \text { 時間) } \\
\end{array}$ & $\begin{array}{r}583 \\
(40.5) \\
\end{array}$ & $\begin{array}{c}654 \\
(45.4) \\
\end{array}$ & $\begin{array}{c}199 \\
(13.8) \\
\end{array}$ & $\begin{array}{c}5 \\
(0.3) \\
\end{array}$ & $\begin{array}{l}1441 \\
(100) \\
\end{array}$ \\
\hline $\begin{array}{c}\mathrm{H} 78.22 \sim 11.22 \\
\text { (2233 時間) }\end{array}$ & $\begin{array}{r}797 \\
(35.7) \\
\end{array}$ & $\begin{array}{r}937 \\
(42.0) \\
\end{array}$ & $\begin{array}{c}450 \\
(20.2) \\
\end{array}$ & $\begin{array}{c}49 \\
(2.2) \\
\end{array}$ & $\begin{array}{l}2233 \\
(100) \\
\end{array}$ \\
\hline $\begin{array}{c}\text { H 7 8.22 12. } 13 \\
\text { (2737 時間) } \\
\end{array}$ & $\begin{array}{c}1074 \\
(39.2)\end{array}$ & $\begin{array}{c}1089 \\
(39.8) \\
\end{array}$ & $\begin{array}{c}522 \\
(19.1) \\
\end{array}$ & $\begin{array}{c}52 \\
(1.9) \\
\end{array}$ & $\begin{array}{l}2737 \\
(100)\end{array}$ \\
\hline $\begin{array}{c}\text { H 7 8.22 2.22 } \\
\text { (4443 時間) } \\
\end{array}$ & $\begin{array}{l}1619 \\
(36.5) \\
\end{array}$ & $\begin{array}{c}1872 \\
(42.2) \\
\end{array}$ & $\begin{array}{c}854 \\
(19.2) \\
\end{array}$ & $\begin{array}{c}96 \\
(2.2) \\
\end{array}$ & $\begin{array}{l}4443 \\
(100) \\
\end{array}$ \\
\hline
\end{tabular}

この 3 ケースの計算手法の比較を表-1に示す.

ここで, 露出した稚貝の, 海中における移動の追跡は, 観測期間(平成 7 年 8 月 22 日〜平成 8 年 2 月 22 日, 合計 4443 時間) 中の 1 時間ごとの移動経路, 及び通過する波 浪の累積による減耗を計算できるように, 初期位置, 及 び殸長を共通項とする個体群をラグランジュ的に追跡す ることとした. また表一 2 には, 再現計算に用いた, 平成 7 年度現地調查期間中の時化のプロフィールを示す.

\section{1 平成 7 年度現地調查結果の再現}

平成 7 年度については, 1 歳貝の分布個体数が多いた め, 1 歳貝を対象とした平成 7 年度調査結果の時系列変 化, すなわち個体数密度, 及び平均款長の 2 点について 再現を試みる. 計算領域内の初期個体密度, 及び壳長分 布は, 実測值の分布とし, 移動条件 3 ケースの再現性を 検証した. 稚貝の個体数分布が最も多い測線 1 における 「平均殼長変化」, 「個体数密度変化」の再現状況を図一 7 , 8 に示す.このうち成長率 (平均殼長変化) は, 水温のみ に依存する関数として与えているため, 移動条件による 差異は生じない.

平均殼長の時系列的変化については, 計算值は実測を 非常によく再現しているといえる. 測線 1 の個体数密度 変化についてみると, 8 月 21 日に水深 $9.10 \mathrm{~m}$ を中 に, 高密度で分布していた稚貝は波浪により減耗され, 日数とともに密度が減少している. 実測值をモデルによ

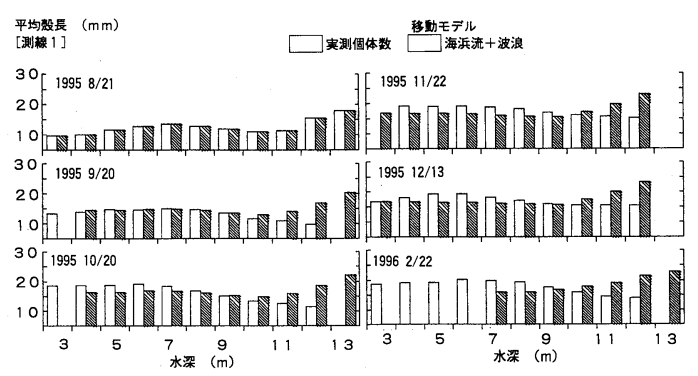

図一7 平成 7 年度現況再現計算 平均殼長変化図

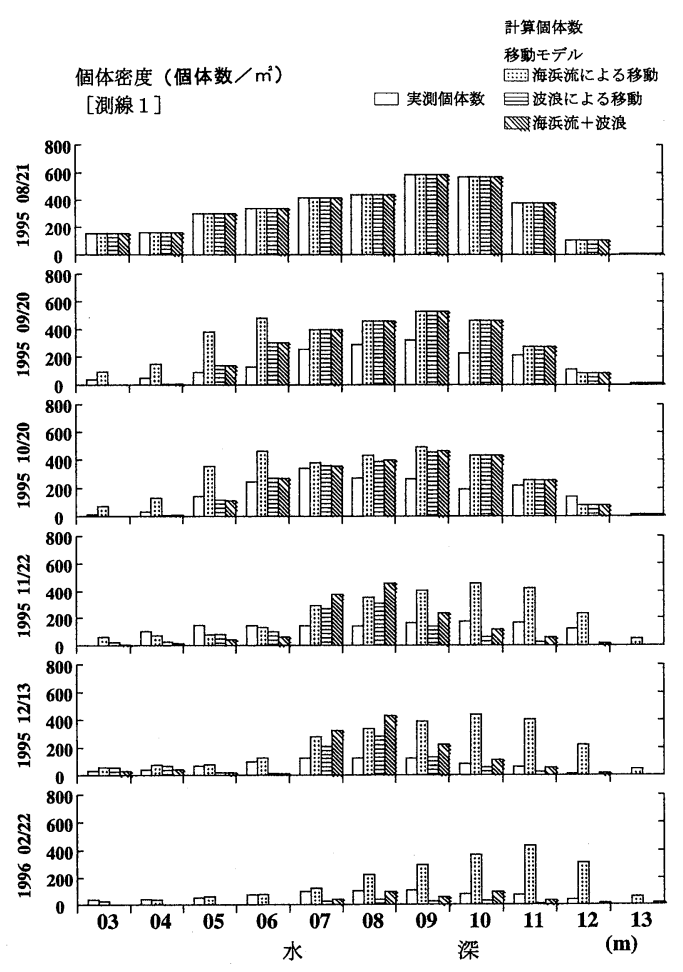

図-8 平成 7 年度現況再現計算 個体密度変化図

る再現計算と比較すると, 波浪と海浜流による貝の移動 を計算したものが 1 番良く, 稚貝分布の時系列変化の傾 向をとらえていることがわかる.

\section{2 港湾周辺域における稚貝分布特性について}

ここでは, 平成 7 年度 1 歳貝の現地調査結果と, 資源 変動モデルを用いた, 稚貝生残の数值計算結果を比較す ることにより, 港湾周辺域における稚貝分布特性につい て考察する.

シルト含有率, 平均波高, 個体数密度分布の現地調査 結果を, 時系列変化を考慮し, 水深別に図一9, 10, 11 に 示す.まず，港内に位置する測線 2 に着目する. 調査期 間中の平均波高は, 他の 2 測線に比べ非常に小さく, 測 線 2 周辺が静穏であるため, 水深帯 $-8 \mathrm{~m}$ 以深のシルト 

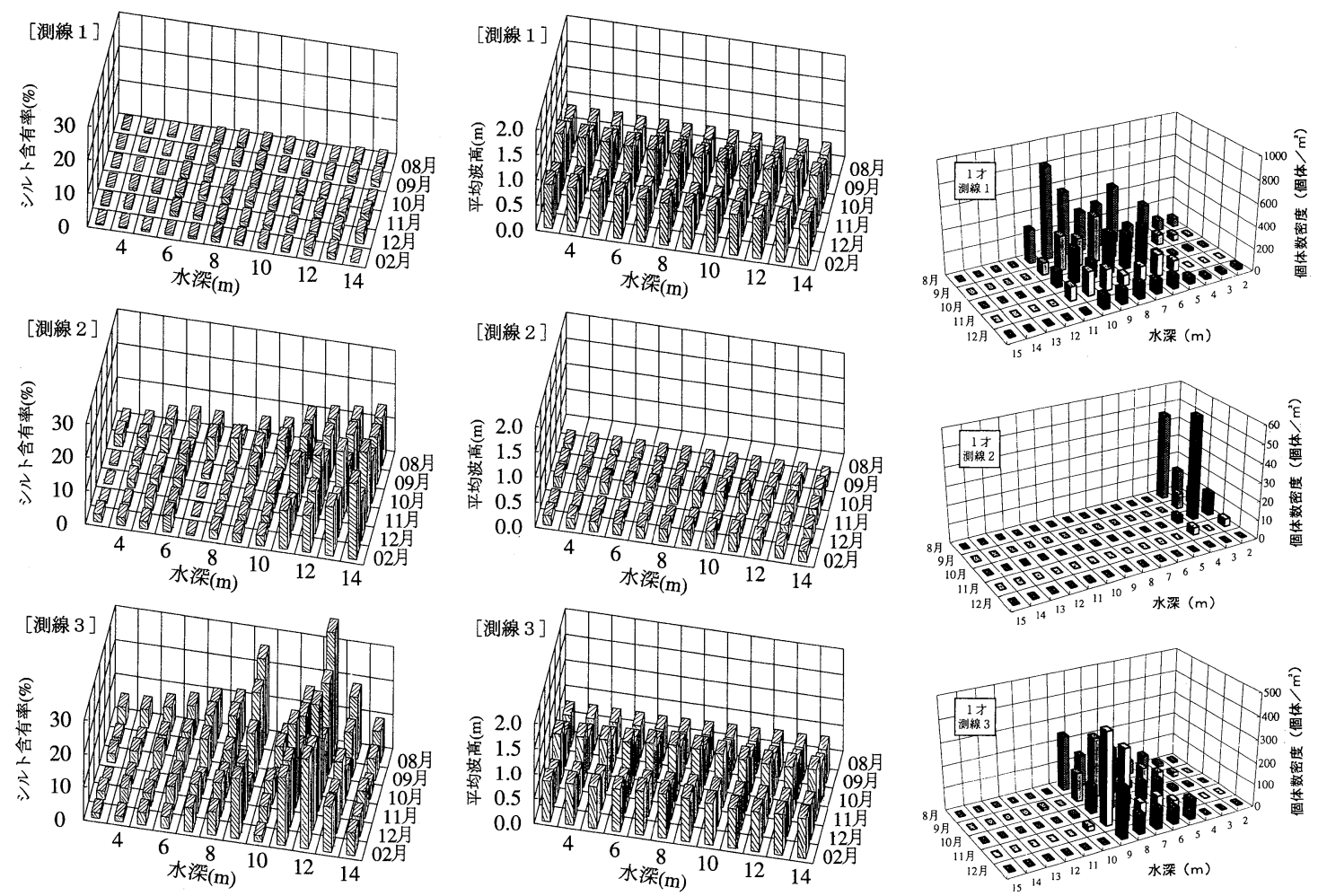

図一9 平成 7 年シルト含有率調查結果

図-10 平成 7 年平均波高調査結果

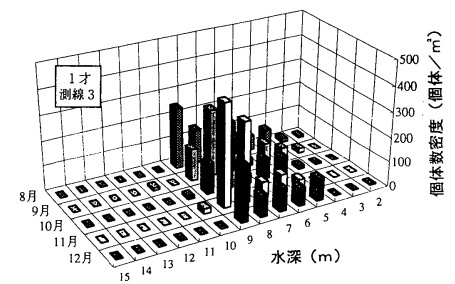

図-11 平成 7 年度稚貝出現状況図

含有率が総じて高い.この結果を反映して,$-4 \mathrm{~m}$ 以浅の 水深帯を除き，測線 2 では稚貝がほとんど分布していな い. それとは対照的に, 港湾構造物の影響の少ない測線 1 では調査期間を通じて，ある程度の波高が卓越し，か つ 3 測線中で最もシルト含有率が低いことから，3測線 中最も高い個体数分布が得られている。この 2 測線に対 し，港内ではないが東港区周辺域に相当する測線 3 につ いて調查結果を見る. シルト含有率は, 水深 $-7 \sim-13 \mathrm{~m}$ 領域において，3 測線中最も高い分布域であるにもかか わらず, 港内の測線 2 と異なり, $-5 \sim-9 \mathrm{~m}$ 領域で, 比較 的高い密度分布域を形成している。平均波高は, 全水深 帯で測線 1 と同じ程度に卓越することより, 防波堤建設 により卓越する海浜流による, 稚貝の集積効果が推察さ れる.

そこで, この資源変動モデルを用い, 初期密度を実測 密度と初期密度一様の 2 ケースについて, 稚貝の生残を 計算することにより, 港湾構造物周辺の稚貝分布特性を 考察する.一様初期密度は, 1 歳貝の平成 7 年度実測値 平均である, $300 \mathrm{ind} / \mathrm{m}^{2}$ で与える. 平均殼長は, 1 歳貝の 平成 7 年度実測值平均である $13 \mathrm{~mm}$ とする. なお,ここ での計算の移動条件は, 最も再現性の良かった波浪と海 浜流で行った。

港湾周辺域の稚貝分布特性を，防波堤による海浜流の

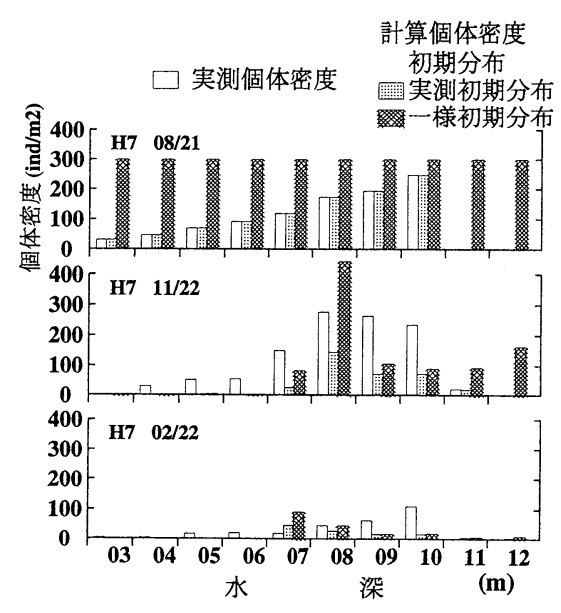

図一12 波浪と海浜流による移動モデル

影響が大きい測線 3 の計算結果で考察する. 実測値分布 と, 初期一様分布双方の計算結果を比較して示したもの が，図一12である。

実測值分布では，8月 21 日に水深が深くなるほど，高 密度で分布していた稚貝は，11月 22 日には海浜流によ り, 水深 8〜 $10 \mathrm{~m}$ に集積させられていることがわかる. 実測初期密度の再現計算でもこの傾向はでているが, 初 
（波浪十海浜流による移動モデル）

初期一様分布

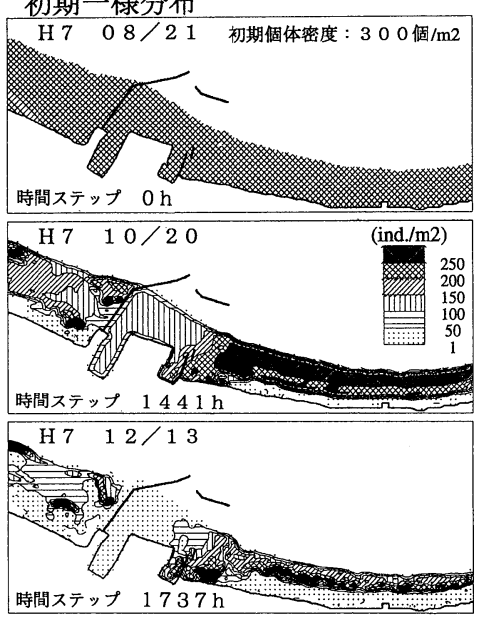

図一13 初期一様分布計算 個体数密度分布図

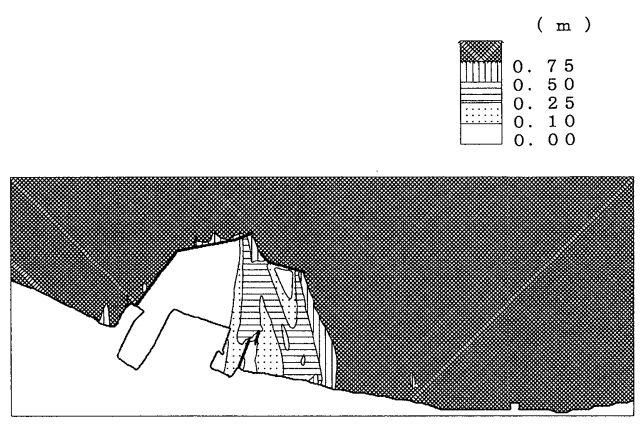

図-14 波高エネルギー平均のルート

期密度一様とした計算結果では, さらにこの傾向がよく とらえられている，図一13 は，初期密度一様で与えた平 面分布の計算結果である。また，図一14 は計算期間（合 計 4442 時間) の波高エネルギー平均のルートをとった 3 連の分布図. 図一15 は波高 $2 \mathrm{~m}$ を境界入力した海浜流場 の計算結果である. 図一13 と図一14, 15 を対照すると， 港両側に発達する海浜流による貝の集積効果と, 港周辺 の静穏域での貝の減耗の減少により, 港両側に貝の高密 度域が形成されることがわかる．このことが, 港湾建設 に伴うウバガイ資源量の増加の原因の 1 つと考元られ る.

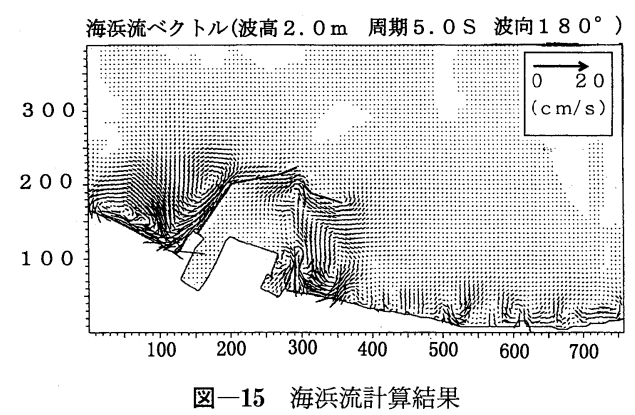

\section{6. 結 論}

本研究で得られた主要な結論を以下に述べる.

(1) 室内実験を含む 2 ヶ年の現地調査により, 苫小牧 海域に扔けるウバガイ稚貝の, 餌料環境と成長特性, シ ルト含有率等の減耗要因, 及び貝の移動特性を明らかに した。

(2) 成長，減耗，移動モデルの 3 つり構成される， ウバガイ稚貝の資源変動モデルによる再現計算で, 平均 殼長及び個体数密度分布の 2 点について, 平成 7 年度現 地調査結果の時系列変化が，比較的良く再現できた。

(3) 初期密度を全域一様分布で与えた計算により，港 湾構造物周辺に発達する海浜流等の結果による貝の集積 効果と，静穏域に抢ける貝の減耗抑制効果を，この資源 変動モデルで表現できた.

\section{参 考 文 献}

明田定満・宮本義憲・谷野賢二・佐藤 仁・桑原伸司 (1993)：防 波堤延長に伴うホッキ貝分布域の変遷，海岸工学論文集，第 40 巻, pp. 1156-1160

平野明徳 (1996)：二枚貝の資源変動と水理環境特性，平成 7 年 度北海道大学修士論文.

中村義治・田口 哲・飯泉 仁・三村信男・村井克詞 (1995)：二 枚貝の餌料環境と資源変動モデルに関する一考察, 海岸工学 論文集, 第 42 巻, pp. 1121-1125.

中村義治・三村信男・秋元義正 (1990)：波による二枚貝の輸送 モデルと漁場形成機構, 海岸工学論文集, 第 37 巻, pp. 818822.

山下俊彦・松岡 学 (1994): 波浪による二枚貝の挙動と減耗に 関する実験的研究，海洋開発論文集，Vol. 10, pp. 119-122.

山下俊彦・和田 彰・鳴海日出人・渥美洋一・桜井 泉 (1997): 振動流場でのウバガイ稚貝の潜砂に関する実験的研究, 海洋 開発論文集, Vol. 13 (印刷中).

山下俊彦・和田 彰・松岡 学 - 谷野賢二 ・ 明田定満 (1995)：振 動流場での二枚貝の挙動に関する実験的研究, 海岸工学論文 集, 第 42 巻, pp. 506-510. 